\title{
Investigation of in vitro Antileishmanial Activity of Moxifloxacin, Linezolid and Caspofungin on Leishmania tropica Promastigotes
}

\author{
Leishmania tropica Promastigotları Üzerine Moksifloksasin, Linezolid ve Kaspofunginin
}

in vitro Antileishmanial Etkisinin Araştırılması

\section{Mehmet Emin Limoncu', Bayrı Eraç², Tuğba Gürpınar³, Ahmet Özbilginn', I. Cüneyt Balcığlu4, Mine Hoşgör-Limoncu ${ }^{2}$}

'Vocational School of Health Services, Celal Bayar University, Manisa, Turkey

2Department of Pharmaceutical Microbiology, Faculty of Pharmacy, Ege University, İzmir, Turkey

${ }^{3}$ Department of Pharmacology, Faculty of Medicine, Celal Bayar University, Manisa, Turkey

${ }^{4}$ Deparment of Parasitology, Faculty of Medicine, Celal Bayar University, Manisa, Turkey

\section{ABSTRACT}

Objective: This study aimed to evaluate the potential in vitro anti-leishmanial activities of moxifloxacin, linezolid and caspofungin against Leishmania tropica.

Methods: In vitro effects of all agents were studied by using the microdilution method. For this purpose, serial dilutions of the aforementioned agents were prepared in concentrations between $4096 \mu \mathrm{g} / \mathrm{mL}-0.008 \mu \mathrm{g} / \mathrm{mL}$. Afterwards, promastigotes incubated in suitable medium were counted with the hemocytometer and adjusted as having a last concentration of $2.5 \times 10^{6} \mathrm{cell} / \mathrm{s} / \mathrm{mL}$ in wells containing medium + antibiotic or antifungal. After incubation live promastigotes were counted with the hemocytometer and inhibitor concentrations $\left(\mathrm{IC}_{50}\right)$ were determined by comparing with the control that contained no antibiotics or antifungal.

Results: $I C_{50}$ values of moxiloxacin, linezolid and caspofungin were found as $194.7 \mu \mathrm{g} / \mathrm{mL}, 896 \mu \mathrm{g} / \mathrm{mL}$ and $235.7 \mu \mathrm{g} / \mathrm{mL}$, respectively.

Conclusion: As a result, moxifloxacin was found to be effective in lower concentrations than the other studied agents against $L$. tropica promastigotes. (Turkiye Parazitol Derg 2013; 37: 1-3)

Key Words: Leishmania tropica, antileishmanial activity, moxifloxacin, linezolid, caspofungin

Received: 05.06.2012

Accepted: 16.01 .2013

\section{ÖZET}

Amaç: Bu çalışmada, Leishmania tropica üzerine moksifloksasin ve linezolid ile kaspofunginin, potansiyel anti-leishmanial etkilerinin in vitro olarak araştırılması amaçlandı.

Yöntemler: Tüm ajanların in vitro etkisi mikrodilüsyon yöntemiyle araştııılı. Bu amaçla moksifloksasin, linezolid ve kaspofunginin 4096 g $/ \mathrm{mL}-0.008$ $\mu \mathrm{g} / \mathrm{mL}$ arasındaki konsantrasyonlarda seri dilüsyonları yapıldı. Ardından uygun besiyerinde inkübe edilen promastigotlar hemositometre ile sayıldı

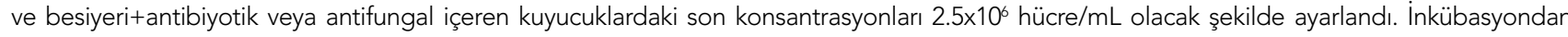
sonra canlı promastigotlar hemositometre ile sayıldı ve ajanların \%50 inhibitör konsantrasyonları ( $\left(\mathrm{K}_{50}\right)$ kontrollerle karşılaştıılarak belirlendi.

Bulgular: Moksifloksasin, linezolid ve kaspofunginin in vitro $\mathrm{IK}_{50}$ değerleri sırasıyla $194.7 \mu \mathrm{g} / \mathrm{mL}$, $896 \mu \mathrm{g} / \mathrm{mL}$ ve $235.7 \mu \mathrm{g} / \mathrm{mL}$ olarak bulundu. Sonuç: Moksifloksasinin, L. tropica promastigotlarına karşı çalışılan diğer ajanlara göre daha düşük konsantrasyonlarda etkili olduğu sonucuna varıldı. (Turkiye Parazitol Derg 2013; 37: 1-3)

Anahtar Sözcükler: Leishmania tropica, antileishmanial activite, moxifloxacin, linezolid, caspofungin

Geliş Tarihi: 05.06.2012

Kabul Tarihi: 16.01.2013

This study was presented in Gülhane Microbiology Days, Antimicrobial Chemotherapy Laboratory Practices and New Approaches, 2010, istanbul, as a poster.

Address for Correspondence / Yazışma Adresi: Dr. Bayrı Eraç, Department of Pharmaceutical Microbiology, Faculty of Pharmacy, Ege University, İzmir, Turkey Phone: +90 2323114083 E-mail: bayri.erac@ege.edu.tr, eracb@yahoo.com

doi:10.5152/tpd.2013.01 


\section{INTRODUCTION}

Leishmaniasis is an important tropical disease which influences 20 million people in 80 countries worldwide and 350 million people are at risk. Cutaneus leishmaniasis (CL) is being reported in many areas of our country, especially from Southeast Anatolia, Mediterranean and Aegean Regions of Turkey (1). Currently, the, first choice of treatment for the disease is still pentavalent antimony compounds. Recently, increase in the number of resistant cases for these compounds and inefficacy of the treatment in immunosuppressive individuals have been observed. It is determined that pump mediated multiple drug resistance has a part in resistance development (2). Alternative treatment options have been investigated, because current drugs have only limited effect on leishmaniasis and are toxic and expensive $(3,4)$.

Nowadays, effects of intracellularly active antibiotics and antifugal agents have been researched on Leishmania amastigotes and promastigotes $(5,6)$. Quinolones are synthetic antibacterial drugs and nalidixic acid is a prototype antibiotic of this class. It acts by inhibiting DNA topoisomerase type II (girase) or topoisomerase type IV, that are responsible for DNA replication, recombination and repair in bacteria. Moxifloxacin is a broad spectrum fluoroquinolone and is active against Gram-positive, Gram-negative and atypical pathogens. In addition, it can be taken once daily.

Linezolid is the first oxazolidinone derivation that is used clinically. It deteriorates the tRNA binding site by bonding the $50 \mathrm{~S}$ ribosomal subunit and therefore formation of 705 initiation complex is prevented (7). Echinocandins are semisynthetic lipopeptide compounds which inhibit 1,3- $\beta$-glucan synthesis, an important component of thefungus cell wall. They show selective toxicity because mammalian cells do not include $1,3-\beta$-glucan. The most known member of this group is caspofungin and others are also available (8).

In this study, we aimed to evaluate the potential in-vitro antileishmanial activities of moxifloxacin, linezolid and caspofungin against Leishmania tropica (MHOM/TR/10/CBU52).

\section{METHODS}

\section{Parasite}

In our study, L. tropica promastigotes (MHOM/TR/10/CBU52), isolated in Manisa were used.

\section{Agents and Methods}

In this study, in vitro effects of moxifloxacin (Bayer, Turkey), linezolid (Pfizer, Turkey) and caspofungin (Merck Sharp \& Dohme, Turkey) were studied by using the microdilution method according to Clinical Laboratory Standards Institute (CLSI) recommendations (9). For this purpose, serial dilutions of mentioned agents were prepared in concentration between $4096 \mu \mathrm{g} /$ $\mathrm{mL}-0.008 \mu \mathrm{g} / \mathrm{mL}$. Afterwards, promastigotes that had been incubated in RPMI-1640 medium (Sigma), including 5\% fetal-calf serum (FCS), were counted with the hemocytometer and adjusted as having a final concentration of $2.5 \times 10^{6}$ cells $/ \mathrm{mL}$ in wells containing $200 \mu \mathrm{L}$ RPMI+5\% FCS +antibiotic or antifungal. Microplates were incubated for 48 hours in $27^{\circ} \mathrm{C}$. Live promastigotes were counted with the hemocytometer after 48 hours and inhibitor concentrations $\left(\mathrm{IC}_{50}\right)$ were determined by comparing with the control which does not contain antibiotics or antifungal. Amphotericin B (Sigma) $(100 \mu \mathrm{g} / \mathrm{mL}-0.0002 \mu \mathrm{g} / \mathrm{mL})$, that is used for $\mathrm{CL}$ treatment, was used as control. The procedure was performed in triplicate and mean values of the results were calculated.

\section{RESULTS}

$\mathrm{IC}_{50}$ values of moxiloxacin, linezolid and caspofungin were found as $194.7 \mu \mathrm{g} / \mathrm{mL}, 896 \mu \mathrm{g} / \mathrm{mL}$ and $235.7 \mu \mathrm{g} / \mathrm{mL}$, respectively. IC $_{50}$ value of amphotericin B was detected as $0.026 \mu \mathrm{g} / \mathrm{mL}$. IC $C_{50}$ values of studied agents and the number of live promastigotes are shown in Table 1.

\section{DISCUSSION}

Cutaneus leishmaniasis is common in many regions of the world, including our country. Today, the increasing number of patients with immune deficiency increases the incidence of opportunistic Leishmania infections. Use of pentavalent antimony compounds, that is the first choice of leishmaniasis treatment, was restricted due to several side effects and resistance development (10). Thus, new treatment options are being considered.

One of the groups among the alternative treatment choices is antifungal agents. Amphotericin B is the most commonly used one in this group and it was approved by Food and Drug Administration (FDA) for the treatment of visceral leishmaniasis. Efficacy of azoles such as ketoconazole, itraconazole and flucon-

Table 1. The in vitro effects of various agents on $L$. tropica

\begin{tabular}{|c|c|c|c|}
\hline Agents & $\begin{array}{c}\mathrm{IC}_{50} \\
(\mu \mathrm{g} / \mathrm{mL})\end{array}$ & $\begin{array}{l}\text { Concentrations } \\
(\mu \mathrm{g} / \mathrm{mL})\end{array}$ & $\begin{array}{c}\text { Number of } \\
\text { Promastigots } \\
\left(\times 10^{4}\right)\end{array}$ \\
\hline \multirow[t]{6}{*}{ Moxifloxacin } & \multirow[t]{6}{*}{194.7} & 4096 & 0 \\
\hline & & 2048 & 0 \\
\hline & & 512 & 1 \\
\hline & & 256 & 12 \\
\hline & & 128 & 25 \\
\hline & & 16 & 35 \\
\hline \multirow[t]{6}{*}{ Linezolid } & \multirow[t]{6}{*}{896} & 4096 & 6 \\
\hline & & 2048 & 14 \\
\hline & & 512 & 25 \\
\hline & & 256 & 30 \\
\hline & & 128 & 35 \\
\hline & & 16 & 35 \\
\hline \multirow[t]{6}{*}{ Caspofungin } & \multirow[t]{6}{*}{235.7} & 4096 & 0 \\
\hline & & 2048 & 0 \\
\hline & & 512 & 6 \\
\hline & & 256 & 16 \\
\hline & & 128 & 20 \\
\hline & & 16 & 30 \\
\hline Amphotericin B & 0.26 & & \\
\hline
\end{tabular}


azole that inhibit ergosterol synthesis in fungus was tested on leishmania species (11). Caspofungin is a new antifungal agent and prevents fungus cell wall synthesis. A limited number of studies were made researching the efficacy of caspofungin against some species of protozoa. For example, it is found that caspofungin is effective in $250 \mathrm{mg} / \mathrm{L}$ concentration against Acanthomoeba species (12). In the present study, efficacy of caspofungin was investigated in concentrations between 4096$0.008 \mu \mathrm{g} / \mathrm{mL}$ on L. tropica, and the $\mathrm{IC}_{50}$ value was found as 235 $\mu \mathrm{g} / \mathrm{mL}$. Studies on in vivo efficacy of caspofungin in different Leishmania species will establish a better evaluation of possibility for using this agent in leishmaniasis treatment.

There are a limited number of studies evaluating the efficacy of linezolid on protozoa. In a study regarding to efficiency of linezolid on Plasmodium falciparum, protein synthesis inhibitor drugs such as doxycycline and azithromycin were used as controls and antimalarial effects of these antibiotics was attributed to being active against prokaryote organelles such as mitochondria and apicoplast. However, it was found that linezolid is not as efficient as others (13). In an immunodeficient patient wtih acute granulomatous Acanthamoeba encephalitis, combination therapy with linezolid, meropenem, moxifloxacin and fluconazole were found effective in survival (14). In the present study, the $I C_{50}$ value of linezolid, studied in concentrations between 4096-0.008 $\mu \mathrm{g} / \mathrm{mL}$, was found as a very high value of $896 \mu \mathrm{g} / \mathrm{mL}$. The low efficacy of linezolid against Leishmania was attributed to the different ribosome structure between parasites and bacteria.

Studies investigating the efficacy of fluoroquinolon antibiotics in treatment of clinical leishmaniasis, are available $(5,15)$. It was stated that DNA topoisomerase enzymes of trypanosomatide parasites (Leishmania spp. and Trypanosoma spp.) are potential targets in terms of selective inhibition. These enzymes have significant structural and biochemical differences compared to their homologues present in humans $(5,10)$. It was also found that topoisomerase II inhibitors are effective against Trypanosoma cruzi and L. donovani amastigotes (16). In our study, $I_{50}$ value of moxifloxacin was found $194.7 \mu \mathrm{g} / \mathrm{mL}$ and this is the lowest value among the studied agents. It was reported that some newly synthesized fluoroquinolone derivations are effective against Toxoplasma gondii and blood phases of P. falciparum (17). Also, it was detected that fluoroquinolones are efficient against Leishmania species in animal models and human macrophages cell lines $(10,15,16)$. Van Der Vliet et al. (15) reported a suppurative Pseudomonas aeruginosa otochondritis along with CL ulceration and it is determined that ciprofloxacin is effective for treatment of this infection. Hence, fluoroquinolones can be used both for Leishmania infections and for secondary bacterial infections that may occur.

\section{CONCLUSION}

Moxifloxacin was found to be effective in lower concentrations than the other studied agents against $L$. tropica promastigotes and it was considered that it can be used as an alternative treat- ment agent. Evaluation of the in-vivo effects of linezolid, caspofungin and especially moxifloxacin is required for providing more detailed information.

\section{Conflict of Interest}

No conflict of interest was declared by the authors.

\section{REFERENCES}

1. Ok ÜZ, Balcıoğlu iC, Taylan OA, Özensoy S, Özbel Y. Leishmaniasis in Turkey. Acta Trop 2002; 84: 43-8. [CrossRef]

2. Mandal G, Sarkar A, Saha P, Singh N, Sundar S, Chatteriee M. Functionality of drug efflux pumps in antimonial resistant Leishmania donovani field isolates. Indian J Biochem Biophys 2009; 46: 86-92.

3. Chan-Bacab MJ, Pena-Rodriquez LM. Plant natural products with leishmanicidal activity. Nat Prod Rep 2001; 18: 674-88. [CrossRef]

4. Sharief AH, Gasim Khalil EA, Theander TG, Kharazmi A, Omer SA, Ibrahim ME. Leishmania donovani: an in-vitro study of antimonyresistant amphotericin B-sensitive isolates. Exp Parasitol Dec 2006; 114: 247-52. [CrossRef]

5. Romero IC, Saravia NG, Walker J. Selective action of fluoroquinolones against intracellular amastigotes of Leishmania (Viannia) panamensis in-vitro. J Parasitol 2005; 91: 1474-9. [CrossRef]

6. Yardley V, Croft SL. Activity of liposomal amphotericin B against experimental cutaneous leishmaniasis. Antimicrob Agents Chemother 1997; 41: 752-6.

7. Jacoby GA. Mechanisms of resistance to quinolones. Clin Infect Dis 2005; 41: 120-6. [CrossRef]

8. Perlin DS. Current perspectives on echinocandin class drugs. Future Microbiol 2011; 6: 441-57. [CrossRef]

9. Clinical and Laboratory Standards Institute Methods for dilution antimicrobial susceptibility tests for bacteria that grow aerobically; Approved Standard, 7th ed. CLSI document M7-A7, Wayne, PA, USA. $2006 b$.

10. Cortazar TM, Coombs GH, Walker J. Leishmania panamensis: comparative inhibition of nuclear DNA topoisomerase II enzymes from promastigotes and human macrophages reveals anti-parasite selectivity of fluoroquinolones, flavonoids and pentamidine. Exp Parasitol 2007; 116: 475-82. [CrossRef]

11. Alrajhi AA. Cutaneous leishmaniasis of the old world. Skin Ther Lett 2003; 8: 1-4.

12. Bouyer S, Imbert C, Daniault G, Cateau E, Rodier MH. Effect of caspofungin on trophozoites and cysts of three species of Acanthamoeba. J Antimicrob Chemother 2007; 59: 122-4. [CrossRef]

13. Barthel D, Schlitzer M, Pradel G. Telithromycin and quinupristindalfopristin induce delayed death in Plasmodium falciparum. Antimicrob Agents Chemother 2008: 52: 774-7. [CrossRef]

14. Lackner P, Beer R, Broessner G, Helbok R, Pfausler B, Brenneis C, et al. Acute granulomatous acanthamoeba encephalitis in an immunocompetent patient. Neurocrit Care 2010; 12: 91-4. [CrossRef]

15. Van Der Vliet D, Le Guern AS, Freitag S, Gounod N, Therby A, Darie $\mathrm{H}$, et al. Pseudomonas aeruginosa otochondritis complicating localized cutaneous leishmaniasis: prevention of mutilation by early antibiotic therapy. Am J Trop Med Hyg 2006; 75: 270-2.

16. Vouldoukis I, Rougier S, Dugas B, Pino P, Mazier D, Woehrlé F. Canine visceral leishmaniasis: comparison of in-vitro leishmanicidal activity of marbofloxacin, meglumine antimoniate and sodium stibogluconate. Vet Parasitol 2006; 135: 137-46. [CrossRef]

17. Anquetin G, Rouquayrol M, Mahmoudi N, Santillana-Hayat M, Gozalbes R, Greiner J, et al. Synthesis of new fluoroquinolones and evaluation of their in-vitro activity on Toxoplasma gondii and Plasmodium spp. Bioorg Med Chem Lett 2004; 7: 2773-6. [CrossRef] 